\title{
A Case Study of the Phenotypic Variations in Barilius bendelisis (Hamilton) from a Perennial Stream and a Fish Pond of Garhwal Himalayan Region of Uttarakhand, India
}

\author{
Pranav Singh ${ }^{1 *}$, Shivani Nautiyal ${ }^{2}$, Navneet Swami ${ }^{2}$, Jitendra Singh Rana ${ }^{2}$, Manju Prakash Gusain ${ }^{2}$, \\ Om Prakash Gusain ${ }^{2}$ \\ ${ }^{1}$ Department of Zoology, Hemvati Nandan Bahuguna Garhwal University, SRT Campus, Badshahithaul, Tehri \\ (Garhwal) 249199, Uttarakhand, India \\ ${ }^{2}$ Freshwater Biology Unit, Department of Zoology and Biotechnology, Hemvati Nandan Bahuguna Garhwal \\ University, Srinagar (Garhwal) 246174, Uttarakhand, India
}

Article history:

Submission May 2020

Revised June 2020

Accepted August 2020

*Corresponding author:

E-mail: pranavfreshbio@gmail.com

\begin{abstract}
A comparative study on the morphometric and meristic variables of Barilius bendelisis (Ham.) from two different water bodies, i.e., Khanda Gad, a perennial spring fed stream and fish pond in the Garhwal Himalayan region of Uttarakhand was made during the present study. A total of 100 specimens were analysed for 26 different morphometric variables and 14 meristic counts. All morphometric variables showed linear relationship when expressed in relation to total length and head length (except for caudal length in Khanda Gad's fishes). As observed by meristic counts for different length of fishes, it remained constant with increasing body length. Standard length was found to be the highly correlated character in samples from both sites. Principal Component Analysis of 10 significant morphometric variables yielded three components accounting for $73.38 \%$ of the total variation. Principal Component Analysis of 3 meristic variables yielded single component accounting for $62.3 \%$ of total variation. Principal Component Analysis plots show that characters like, base of caudal fin, least height of caudal peduncle, pre-orbital distance, post-orbital distance, eye diameter, inter orbital distance, numbers of dorsal fin ray, scales from lateral line to pelvic fin and scales from lateral line to anal fin distinguishes the fish stock from fish pond and Kanda Gad. Discriminant Function Analysis for morphometric and meristic variables showed that $98 \%$ and $83 \%$ of individuals were allocated into their original populations respectively. The cluster analysis for morphometric characters showed of fish populations from both sites formed two major clades, thus significantly differentiating the two stocks of fish population. These morphometric variations could be attributed to the difference in the ecological and the rearing condition of fish stock from the stream and pond. The information on phenotypic variation between the natural stream and hatchery reared fish would be important for development of aquaculture.
\end{abstract}

Keywords: Discriminant function analysis, Morphometric measurement, Phenotypic characters, Principal component analysis

\section{Introduction}

Morphometry plays an important role in identification and establishing the systematic position of fishes. Such taxonomic tools are also useful in detecting variations in the fish population. The morphometric features of a fish are subjected to adaptations under various habitat conditions.
Change in the hydrological conditions leads to the morphometric variations in the fish stocks [1]. Instead of direct genetic control, the morphometric variation has been suggested to influence by the environmental factors [2, 3]. Handful knowledge of about environmentally influenced variation in

\section{How to cite:}

Singh P, Nautiyal S, Swami N et al. (2020) A Case Study of the Phenotypic Variations in Barilius bendelisis (Hamilton) from a Perennial Stream and a Fish Pond of Garhwal Himalayan Region of Uttarakhand, India. Journal of Tropical Life Science 10 (3): 185 - 196. doi: 10.11594/jtls.10.03.02. 
fish population can be gathered through the study of morphometric variation between fish stocks, which can further help in management of fisheries practices [4, 5]. Therefore, morpho-meristic measurements and counts were considerably used to recognize the variations among fish populations $[6,7]$. The morphological plasticity because of the environmental inconsistency is commonly found among many fish species and the phenotypic variation due to the environmental variation has been extensively used to study the different population stocks [8, 3]. The morphological variability is significant adaptive strategy for populations experiencing environmental variation and the development of response towards the environment and learning leads to the phenotypic variations between wild and cultured fishes [8, 9].

Barilius bendelisis (Ham.) belongs to the order cypriniformes and commonly known as Indian Hill Trout [3]. It dwells in shallow clear water in streams of the Himalayan region including Uttarakhand (India). The species distribution has also been reported from Pakistan, Nepal, Bangladesh, Srilanka, Bhutan and Mayanmar [10, 11, 12]. The species is characterised by 12 black bands running from dorsal to ventral on the body surface, and a single black spot on the base of each body scale [13]. B. bendelisis (Ham.) is in the least concerned category of IUCN, however, it is a popular ornamental species and a food source for the local population which leads to its reduction [14], although it has no commercial value because of its small size, it has an important place in the food chain of hill streams. The objective of the present study was to analyse the variability in the morpho-meristic characteristics of freshwater fish $B$. bendelisis (Ham.) from two different aquatic systems i.e., a perennial stream and a fish pond in the Garhwal region of Uttarakhand. This study should provide information that relates habitat and ecological conditions with the phenotypic variation.

\section{Material and Methods Sample collection}

A total of 50 specimens of $B$. bendelisis (Ham.) were collected from Khanda Gad (306'42"-30¹3'23" N; 78 41'48"-79 ${ }^{\circ} 5^{\prime} 4 "$ E), originating from Mandakhal ridge $(2143 \mathrm{~m}$ above sea level), a left side spring fed tributary of River Alaknanda, $21 \mathrm{Km}$ from the Srinagar township in the Pauri district of Uttarakhand, India, during
November 2015 to April 2016. The fishes were collected randomly using 'Thali' from upstream and downstream at Khanda Township. 'Thali', a local method employs a meshed towel cloth wrapped around a rim of a stainless-steel plate (thali). An opening on the cloth surface is made for the fishes to enter to eat the bait of roasted flour. Also, 50 specimens of $B$. bendelisis (Ham.) were collected by the dip net from a pond in Fish Hatchery at the Chauras campus of HNB Garhwal University, Tehri district of Uttarakhand, India (latitude $30^{\circ} 13 ' 36.43^{\prime \prime} \mathrm{N}$ and longitude $78^{\circ} 48^{\prime} 08.74 " \mathrm{E}$ ) during the same time period. These fishes were collected from Khanda Gad during November 2014 and stocked in hatchery. The species identification has been done by following the different keys $[10,13,15]$. The morphometric measurements and meristic counts of all the 100 specimens were recorded as outlined in [15]. The morphometric measurements were taken manually with the help of ruler and divider, whereas the counts for meristic characters were taken with the help of lens.

\section{Data analysis}

The measurements were subjected to different statistical analyses using Microsoft Excel, SPSS 20 and PAST. The morphometric variables were analysed for correlation and regression and coefficient of correlation (r) and regression (b) were tested for significance. The regression equation was computed for each dependent variable to fit the straight-line equation:

$$
Y=a+b x
$$

Where, $\mathrm{Y}=$ dependent variable; $\mathrm{a}$ = intercept; $\mathrm{b}$ = slope of regression line; $\mathrm{X}=$ independent variable.

The values of mean, standard deviation, range of percentage and range difference were also calculated for various morphometric characters.

To avoid size variation errors in the specimens the morphometric variables were transformed and normalized according to equation [16]:

$$
M_{s}=M_{o}\left(L_{s} / L_{0}\right)^{b}
$$

Where, Ms = standardized measurement, Mo = measured character length $(\mathrm{mm}), \mathrm{L}_{\mathrm{s}}=$ overall (arithmetic) mean standard length $(\mathrm{mm}), \mathrm{Lo}=$ standard length $(\mathrm{mm})$ 
of specimen, $b=$ estimated for each character from the observed data using the non-linear equation

The univariate analysis of variance (ANOVA) was performed on normalized morphometric measurements to find the significant characters that vary between the two habitat sites. The significant variables were then subjected for Principal Component Analysis (PCA), Discriminant Function Analysis (DFA) and the cluster analysis (Jaccard's similarity index).

\section{Results and Discussions}

Correlation coefficient (r) and Regression coefficient (b) of different morphometric characters of $B$. bendelisis (Ham.) was computed in relation to TL and HL at significance level of $\mathrm{P}<0.01$ and
$\mathrm{P}<0.05$. At Khanda Gad, SL and PrDL were the highly and CL was the least correlated character, while at fish pond the characters such as SL, PrDL, HL and PPD have higher degree of correlation in relation to TL. The HD shows high correlation in relation to HL at both the sites. The test of significance showed that all values were significant at $\mathrm{P}$ $<0.01$. All the characters have been observed to follow linear relationship (Table 1).

The use of ' $r$ ' static indicated SL is most highly correlated morphometric parameter in both samples. Similarly, it has been also found that SL is the most highly correlated body part in $B$. bendelisis (Ham.) from hill streams of Himachal Pradesh [17]. The use of static ' $b$ ' seemed to support these findings. The highest value for regression coefficient (b) was shown by SL in relation to TL

Table 1. Mean, Standard deviation, Correlation coefficient (r) and Regression coefficient (b) of different morphometric characters of B. bendelisis (Ham.) in relation to Total length and Head length in Khanda Gad and Fish Pond

\begin{tabular}{|c|c|c|c|c|c|c|c|c|c|}
\hline \multicolumn{2}{|c|}{ S. No. Parameters } & \multicolumn{3}{|c|}{ Khanda Gad } & \multicolumn{3}{|c|}{ Fish Pond } & \multirow{2}{*}{$\begin{array}{c}\text { Khanda } \\
\text { Gad } \\
\text { b value }\end{array}$} & \multirow{2}{*}{$\begin{array}{c}\text { Fish } \\
\text { Pond } \\
\text { b value }\end{array}$} \\
\hline & & Mean & S.D. & $\mathrm{r}$ & Mean & S.D. & $\mathrm{r}$ & & \\
\hline \multicolumn{10}{|c|}{ In relation to $T L$} \\
\hline 1 & Total length (TL) & 9.70 & 1.91 & - & 12.88 & 1.79 & - & & \\
\hline 2 & Standard length (SL) & 7.77 & 1.65 & $0.993 * *$ & 10.54 & 1.51 & $0.974 * *$ & 0.85 & 0.81 \\
\hline 3 & Caudal Length (CL) & 2.28 & 2.15 & 0.032 & 02.37 & 0.43 & $0.723 * *$ & 0.21 & 0.17 \\
\hline 4 & Head length (HL) & 2.12 & 0.43 & $0.934 * *$ & 02.48 & 0.32 & $0.958 * *$ & 0.21 & 0.17 \\
\hline 5 & Body depth (BD) & 2.01 & 2.91 & $0.349 *$ & 02.37 & 0.10 & $0.920 * *$ & 0.53 & 0.19 \\
\hline 6 & Pre-dorsal distance (PrDL) & 4.49 & 0.96 & $0.987 * *$ & 06.10 & 0.91 & $0.965 * *$ & 0.49 & 0.49 \\
\hline 7 & Post-dorsal distance (PoDL) & 2.44 & 0.48 & $0.970 * *$ & 03.37 & 0.78 & $0.604 * *$ & 0.24 & 0.26 \\
\hline 8 & Pre-pelvic distance (PPD) & 4.02 & 0.88 & $0.969 * *$ & 05.55 & 0.88 & $0.947 * *$ & 0.44 & 0.46 \\
\hline 9 & Length of dorsal fin (LDF) & 1.66 & 0.44 & $0.954 * *$ & 02.31 & 0.52 & $0.916 * *$ & 0.22 & 0.27 \\
\hline 10 & Width of dorsal fin (WDF) & 1.00 & 0.29 & $0.876 * *$ & 01.32 & 0.31 & $0.860 * *$ & 0.13 & 0.14 \\
\hline 11 & Length of anal fin (LAF) & 1.29 & 0.21 & $0.930 * *$ & 01.51 & 0.26 & $0.849 * *$ & 0.10 & 0.12 \\
\hline 12 & Width of anal fin (WAF) & 0.94 & 0.34 & $0.820 * *$ & 01.3 & 0.32 & $0.904 * *$ & 0.14 & 0.16 \\
\hline 13 & Length of pelvic fin (LPF) & 1.15 & 0.24 & $0.878 * *$ & 01.43 & 0.29 & $0.784 * *$ & 0.11 & 0.12 \\
\hline 14 & Width of pelvic fin (WPF) & 0.39 & 1.22 & $0.785 * *$ & 00.51 & 0.25 & $0.505 * *$ & 0.05 & 0.12 \\
\hline 15 & Length of pectoral fin (Lpec.F) & 1.62 & 0.36 & $0.958 * *$ & 02.05 & 0.32 & $0.806 * *$ & 0.18 & 0.14 \\
\hline 16 & Width of pectoral fin (Wpec.F) & 0.50 & 0.15 & $0.868 * *$ & 00.63 & 0.13 & $0.727 * *$ & 0.06 & 0.05 \\
\hline 17 & $\begin{array}{l}\text { Least height of caudal peduncle } \\
\text { (LCPD) }\end{array}$ & 0.85 & 0.22 & $0.924 * *$ & 01.02 & 0.21 & $0.848 * *$ & 0.10 & 0.10 \\
\hline 18 & $\begin{array}{l}\text { Highest height of caudal peduncle } \\
\text { (HCPD) }\end{array}$ & 0.95 & 0.23 & $0.922 * *$ & 01.22 & 0.21 & $0.849 * *$ & 0.11 & 0.10 \\
\hline 19 & Base of Caudal fin (BCF) & 0.85 & 0.22 & $0.924 * *$ & 01.06 & 0.20 & $0.916^{* *}$ & 0.10 & 0.10 \\
\hline \multicolumn{10}{|c|}{ In relation to $H L$} \\
\hline 20 & Head depth (HD) & 1.51 & 0.37 & $0.966 * *$ & 01.90 & 0.37 & $0.88 * *$ & 0.82 & 1.02 \\
\hline 21 & Pre-orbital distance (PrOD) & 0.68 & 0.19 & $0.904 * *$ & 01.33 & 0.18 & $0.849 * *$ & 0.41 & 0.48 \\
\hline 22 & Post-orbital distance (PoOD) & 1.14 & 0.35 & $0.886 * *$ & 01.13 & 0.19 & $0.746 * *$ & 0.71 & 0.44 \\
\hline 23 & Eye diameter (ED) & 0.56 & 0.07 & $0.808 * *$ & 00.55 & 0.09 & $0.521 * *$ & 0.14 & 0.15 \\
\hline 24 & Inter orbital distance (IOD) & 0.46 & 0.07 & $0.807 * *$ & 00.46 & 0.06 & $0.845 * *$ & 0.14 & 0.16 \\
\hline 25 & Snout length (SnL) & 0.69 & 0.20 & $0.872 * *$ & 00.77 & 0.13 & $0.821 * *$ & 0.42 & 0.33 \\
\hline 26 & Inter nostril distance (IND) & 0.41 & 0.06 & $0.710 * *$ & 00.51 & 0.10 & $0.628 * *$ & 0.09 & 0.20 \\
\hline
\end{tabular}

** Correlation is significant at the 0.01 level, * Correlation is significant at the 0.05 level 
Singh P, Nautiyal S, Swami N et al., 2020 / A Case Study of the Phenotypic Variations in Barilius bendelisis

Table 2. Mean and Range values of meristic counts of B. bendelisis (Ham.) collected from Khanda Gad and Fish Pond

\begin{tabular}{clcccccccc}
\hline \multirow{2}{*}{$\begin{array}{c}\text { S. } \\
\text { No. }\end{array}$} & Meristic Character & \multicolumn{3}{c}{ Khanda Gad } & \multicolumn{5}{c}{ Fish Pond } \\
\cline { 2 - 9 } & Mean & Min. & Max. & Range & Mean & Min. & Max. & Range \\
\hline 1 & Lateral line scales count (Ltr.Ln.) & 41.98 & 40 & 45 & 5 & 42.18 & 39 & 45 & 6 \\
2 & Pre-dorsal scales (Pr.Ds.) & 22.14 & 21 & 24 & 3 & 21.98 & 20 & 25 & 5 \\
3 & Lateral transverse scales (Ltr.trs.) & 07.68 & 07 & 09 & 2 & 07.52 & 06 & 09 & 3 \\
4 & Circumpenduncular scales (Circum.) & 06.96 & 06 & 08 & 2 & 06.72 & 06 & 07 & 1 \\
5 & Dorsal fin ray (D.Fr.) & 09.00 & 09 & 09 & 0 & 08.80 & 08 & 09 & 1 \\
6 & Pectoral fin ray (Pec.Fr.) & 15.00 & 15 & 15 & 0 & 15.00 & 15 & 15 & 0 \\
7 & Ventral fin ray (V.Fr.) & 09.00 & 09 & 09 & 0 & 09.00 & 09 & 09 & 0 \\
8 & Anal fin ray (A.Fr.) & 09.88 & 09 & 10 & 1 & 09.74 & 08 & 10 & 2 \\
9 & Caudal fin ray (C.Fr.) & 18.00 & 18 & 18 & 0 & 18.00 & 18 & 18 & 0 \\
10 & Scales from lateral line to pelvic fin & 04.32 & 04 & 05 & 1 & 04.84 & 04 & 07 & 3 \\
& (Lat.Pel.) & & & & & & & & \\
11 & Scales from lateral line to dorsal fin & 08.10 & 08 & 09 & 1 & 08.22 & 08 & 09 & 1 \\
& (Lat.D.) & & & & & & & & \\
12 & Scales from lateral line to anal fin & 04.30 & 04 & 05 & 1 & 04.74 & 04 & 06 & 2 \\
& (Lat.A.) & & & & & & & \\
13 & Pre-Anal scales (Pre.As.) & 21.78 & 21 & 23 & 2 & 22.02 & 19 & 24 & 5 \\
14 & Number of Colour bands & 11.48 & 10 & 12 & 2 & 12.70 & 08 & 15 & 7 \\
\hline
\end{tabular}

at both Khanda Gad and the fish pond.

Meristic counts of fishes from Khanda Gad and Fish pond were recorded. At Khanda Gad, the range of lateral line scales, pre-dorsal scales, lateral transverse scales, circumpenduncular scales and pre-anal scales were 40-45, 21-24, 7-9, 6-8, and 21-23 respectively, while at fish pond it was 39-45, 20-25, 6-9, 6-7 and 19-24 respectively (Table 2). Percentage of various body parameters were computed in relation to TL and HL. At Khanda Gad, the CL and LPF shows the high and least degree of range difference respectively in relation to the total length TL. The maximum and least range of differences in relation to HL was observed for PoOD and IOD respectively. However, at the fish pond, PoDL has a higher range of difference in relation to the TL. The ED showed the higher range of difference followed by PoOD while IOD has the least range difference in relation to HL (Table 3).

According to the classification of [18] based on range differences, in the present study 16 characters were found to be genetic, 5 characters were found to be intermediate and 4 characters were found to be environmental at Khanda Gad. Whereas, 15 characters were found to be genetic, 4 characters were found to be intermediate and 6 characters were found to be environmental in the fish pond (Table 3). Thus, the number of genetically controlled characters is large as compared to intermediate or environmental characters. Therefore, it can be presumed that $B$. bendelisis (Ham.) have restricted zoo geographical distribution because the most of their morphometric variables showed the narrow range difference and are controlled genetically. Evidently, these small fish in the Garhwal region occur mostly in small springfed streams and avoid larger snow-fed rivers.

\section{Multivariate Analysis}

The normalized morphometric data subjected to ANOVA showed that fish specimens from the Khanda Gad and fish pond differed significantly $(\mathrm{P}<0.001)$ in 10 standardized morphometric and 4 meristic variables (Table 4). Only the significant variables were further analysed and subjected to PCA. PCA of 10 morphometric variables yielded three components (Eigen value $>1$ ) accounting for 
Singh P, Nautiyal S, Swami N et al., 2020 / A Case Study of the Phenotypic Variations in Barilius bendelisis

Table 3. Percentage of body parts of B. bendelisis (Ham.) in relation to total length and head length in Khanda Gad and Fish Pond

\begin{tabular}{|c|c|c|c|c|c|}
\hline \multirow{2}{*}{ S. No. } & \multirow{2}{*}{ Body parts } & \multicolumn{2}{|c|}{ Khanda Gad } & \multicolumn{2}{|c|}{ Fish Pond } \\
\hline & & Range of \% & Range difference & Range of \% & Range difference \\
\hline \multicolumn{6}{|c|}{$\%$ age in relation to total length (TL) } \\
\hline 1 & SL & $71.42-85.91$ & 14.48 & 76.66-89.34 & 12.67 \\
\hline 2 & CL & $14.08-20.48$ & 06.40 & $12.62-23.33$ & 10.71 \\
\hline 3 & HL & $19.51-25.71$ & 06.20 & $18.05-23.63$ & 05.58 \\
\hline 4 & $\mathrm{BD}$ & $11.68-17.46$ & 05.78 & $16.05-20.68$ & 04.63 \\
\hline 5 & PrDL & $42.64-50.64$ & 08.00 & $42.01-51.40$ & 09.39 \\
\hline 6 & PoDL & $21.10-28.16$ & 07.06 & $11.42-38.88$ & 27.46 \\
\hline 7 & PPD & 33.70-46.82 & 13.11 & 36.36-48.59 & 12.22 \\
\hline 8 & LDF & $14.45-22.76$ & 08.30 & 13.08-22.72 & 09.64 \\
\hline 9 & WDF & 07.50-17.02 & 09.52 & 08.18-13.63 & 05.45 \\
\hline 10 & LAF & 11.47-15.95 & 04.48 & 08.40-13.84 & 05.44 \\
\hline 11 & WAF & 03.48-12.06 & 08.58 & 07.27-13.07 & 05.79 \\
\hline 12 & LPF & $10.00-15.00$ & 05.00 & 08.40-17.29 & 08.88 \\
\hline 13 & WPF & 02.59-08.82 & 06.22 & 02.63-10.88 & 08.25 \\
\hline 14 & Lpec.F & $14.08-19.14$ & 05.06 & 11.80-18.80 & 06.99 \\
\hline 15 & Wpec.F & 03.89-07.93 & 04.04 & 03.73-09.09 & 05.35 \\
\hline 16 & LCPD & 06.49-11.11 & 04.61 & 06.03-11.48 & 05.45 \\
\hline 17 & HCPD & 06.32-11.90 & 05.57 & 07.27-12.16 & 04.88 \\
\hline 18 & $\mathrm{BCF}$ & 06.49-11.11 & 04.61 & 06.03-10.13 & 04.10 \\
\hline \multicolumn{6}{|c|}{$\%$ age in relation to head length $(H L)$} \\
\hline 19 & HD & $60.00-81.81$ & 21.81 & 45.45-96.29 & 50.84 \\
\hline 20 & PrOD & $23.52-41.37$ & 17.84 & $42.30-62.96$ & 20.65 \\
\hline 21 & PoOD & 41.17-72.41 & 31.23 & $25.92-58.33$ & 32.40 \\
\hline 22 & ED & 20.68-33.33 & 12.64 & $02.30-29.16$ & 26.85 \\
\hline 23 & IOD & 16.66-26.66 & 10.00 & $16.66-25.00$ & 8.33 \\
\hline 24 & SnL & $23.52-52.38$ & 28.85 & $19.23-40.74$ & 21.50 \\
\hline 25 & IND & 13.79-26.66 & 12.87 & $16.66-31.03$ & 14.36 \\
\hline
\end{tabular}

Standard Length (SL), Caudal Length (CL), Head Length (HL), Body Depth (BD), Pre-dorsal distance (PrDL), Post-dorsal distance (PoDL), Pre-pelvic distance (PPD), Length of dorsal fin (LDF), Width of dorsal fin (WDF), Length of anal fin (LAF), Width of anal fin (WAF), Length of pelvic fin (LPF), Width of pelvic fin (WPF), Length of pectoral fin (Lpec.F), Width of pectoral fin (Wpec.F), Least height of caudal peduncle (LCPD), Highest height of caudal peduncle (HCPD), Base of Caudal fin (BCF), Head depth (HD), Pre-orbital distance (PrOD), Post-orbita] distance (PoOD), Eye diameter (ED), Inter orbital distance (IOD), Snout length (SnL), Inter nostril distance (IND).

73.38\% of total variation. The first principal component (Eigen value $=5.021$ ) accounted for $50.21 \%$ of total variation with the highest loading on HL, LAF, LCPD, BCF, HD, PoOD, ED, IOD and $\mathrm{SnL}$ variables. The first principal component is mainly a composition of HL, LCPD and BCF variables with significant loadings. Similarly, the second principal component $($ Eigen value $=1.254)$ explained $12.54 \%$ of total variation was mainly composed of BCF, PrOD, ED and IOD variables with maximum loadings (Table 5).
In the scatter plot of the PCA, the majority of the fish population of stream present on the right axis and the majority of the fish population from fish pond present on the left axis of the plot. So, the very first component has been fairly effective in separating the fish population of the stream from the fish population in the pond and only a very few samples were misclassified. The stream population is distinguished from the pond population by BCF, LCPD, ED, PrOD, PoOD and IOD (Figure 1). PCA of 3 meristic variables yielded 
single component $($ Eigen value $=1.869)$ accounting for $62.3 \%$ of total variation with the highest loading on Lat.Pel. and Lat. A. variables. However, the second component $($ Eigen value $=0.985)$ explained $32.84 \%$ of total variation having D.Fr. variables with maximum loadings (Table 5). In the scattered plot of PCA, for meristic characters, D.Fr., Lat.Pel. and Lat.A. distinguish the two different fish population (Figure 2).

In Box's M test the null hypothesis of equal population covariance matrices were rejected with $\mathrm{df} 1=300$, df2 $=29186.4$ and $\mathrm{F}=3.39(\mathrm{P}<0.00$
0.001). The test for the prediction model found statistically significant $(\mathrm{P}<0.001)$ with Wilk's Lambda $=0.278$ and Chi Square $=110.01$. Similarly, for meristic variables the test for prediction model found statistically significant $(\mathrm{P}<0.001)$ with Wilk's Lambda $=0.487$ and Chi Square $=$ 66.842

The single canonical discriminant function explained $100 \%$ of the variation in morphometry of samples at Eigen value 2.594. The maximum variation on this factor was due to ED, PrOD, PoOD, and IOD. Similarly, for meristic variables,

Table 4. F value (derived from analysis of variance) for morphometric and meristic characters of B. bendelisis (Ham.) collected from Khanda Gad and Fish Pond

\begin{tabular}{|c|c|c|c|c|c|c|c|}
\hline $\begin{array}{l}\text { Morphometric charac- } \\
\text { ters }\end{array}$ & $\begin{array}{l}\text { Wilk’s } \\
\text { Lambda }\end{array}$ & $\mathrm{F}$ & Sig. & $\begin{array}{c}\text { Morphometric char- } \\
\text { acters }\end{array}$ & $\begin{array}{l}\text { Wilk's } \\
\text { Lambda }\end{array}$ & $\mathrm{F}$ & Sig. \\
\hline CL & 0.992 & 0.749 & 0.389 & PoOD* & 0.770 & 29.342 & 0.000 \\
\hline $\mathrm{HL}^{*}$ & 0.854 & 16.690 & 0.000 & ED* & 0.619 & 60.415 & 0.000 \\
\hline $\mathrm{BD}$ & 0.990 & 0.956 & 0.330 & IOD* & 0.789 & 26.262 & 0.000 \\
\hline PrDL & 1.000 & 0.002 & 0.962 & $\mathrm{SnL} *$ & 0.847 & 17.738 & 0.000 \\
\hline PoDL & 0.994 & 0.572 & 0.451 & IND & 0.994 & 0.574 & 0.451 \\
\hline PPD & 0.994 & 0.612 & 0.436 & $\begin{array}{c}\text { Meristic charac- } \\
\text { ters }\end{array}$ & & & \\
\hline LDF & 0.960 & 4.045 & 0.047 & Ltr.Ln. & 0.993 & 0.74 & 0.392 \\
\hline WDF & 0.944 & 5.826 & 0.018 & Pr.Ds. & 0.991 & 0.859 & 0.356 \\
\hline $\mathrm{LAF}^{*}$ & 0.900 & 10.914 & 0.001 & Ltr.trs. & 0.984 & 1.593 & 0.210 \\
\hline WAF & 0.944 & 5.825 & 0.018 & Circum. & 0.907 & 10.08 & 0.002 \\
\hline LPF & 0.958 & 4.250 & 0.042 & D.Fr.* & 0.889 & 12.25 & 0.001 \\
\hline WPF & 0.995 & 0.538 & 0.465 & Pec.Fr. & $\mathrm{a}$ & & \\
\hline LPecF & 0.974 & 2.635 & 0.108 & V.Fr. & $\mathrm{a}$ & & \\
\hline WPecF & 0.946 & 5.545 & 0.021 & A.Fr. & 0.975 & 2.541 & 0.114 \\
\hline LCPD* & 0.854 & 16.693 & 0.000 & C.Fr. & a & & \\
\hline HCPD & 0.957 & 4.377 & 0.039 & Lat.Pel.* & 0.803 & 24.003 & 0.000 \\
\hline $\mathrm{BCF}^{*}$ & 0.888 & 12.333 & 0.001 & Lat.D. & 0.973 & 2.697 & 0.104 \\
\hline $\mathrm{HD}^{*}$ & 0.861 & 15.768 & 0.000 & Lat.A.* & 0.820 & 21.443 & 0.000 \\
\hline PrOD* & 0.686 & 44.849 & 0.000 & Pre.As. & 0.976 & 2.452 & 0.121 \\
\hline
\end{tabular}

Caudal Length (CL), Head Length (HL), Body Depth (BD), Pre-dorsal distance (PrDL), Post-dorsal distance (PoDL), Pre-pelvic distance (PPD), Length of dorsal fin (LDF), Width of dorsal fin (WDF), Length of anal fin (LAF), Width of anal fin (WAF), Length of pelvic fin (LPF), Width of pelvic fin (WPF), Length of pectoral fin (Lpec.F), Width of pectoral fin (Wpec.F), Least height of caudal peduncle (LCPD), Highest height of caudal peduncle (HCPD), Base of Caudal fin (BCF), Head depth (HD), Pre-orbital distance (PrOD), Post-orbital distance (PoOD), Eye diameter (ED), Inter orbital distance (IOD), Snout length (SnL), Inter nostril distance (IND), Lateral line scales count (Ltr.Ln.), Pre-dorsal scales (Pr.Ds.), Lateral transverse scales (Ltr.trs.), Circumpenduncular scales (Circum.), Dorsal fin ray (D.Fr.), Pectoral fin ray (Pec.Fr.), Ventral fin ray (V.Fr.), Anal fin ray (A.Fr.), Caudal fin ray (C.Fr.), Scales from lateral line to pelvic fin (Lat.Pel.), Scales from lateral line to dorsal fin (Lat.D.), Scales from lateral line to anal fin (Lat.A.), Pre-Anal scales (Pre.As.).

a: can't be computed (variables are same)

* characters of fish samples from the two populations which differed significantly $(\mathrm{P}<0.001)$ 
Singh P, Nautiyal S, Swami N et al., 2020 / A Case Study of the Phenotypic Variations in Barilius bendelisis

Table 5. Components Loadings of two principal components for 10 morphometric and 3 meristic measurements of B. bendelisis (Ham.) collected from Khanda Gad and Fish Pond

\begin{tabular}{lcc}
\hline Morphometric characters & PC1 & PC2 \\
\hline HL & 0.841 & 0.033 \\
LAF & 0.612 & 0.239 \\
LCPD & 0.813 & 0.355 \\
BCF & 0.804 & 0.418 \\
HD & 0.760 & 0.195 \\
PrOD & -0.225 & 0.569 \\
PoOD & 0.705 & -0.341 \\
ED & 0.601 & -0.470 \\
IOD & 0.751 & -0.438 \\
SnL & 0.760 & 0.040 \\
Meristic characters & & \\
D.Fr. & 0.150 & 0.985 \\
Lat.Pel. & 0.694 & -0.163 \\
Lat.A. & 0.703 & -0.049 \\
\hline
\end{tabular}

Head Length (HL), Length of anal fin (LAF), Least height of caudal peduncle (LCPD), Base of Caudal fin (BCF), Head depth (HD), Pre-orbital distance (PrOD), Post-orbital distance (PoOD), Eye diameter (ED), Inter orbital distance (IOD), Snout length (SnL), Dorsal fin ray (D.Fr.), Scales from lateral line to pelvic fin (Lat.Pel.), Scales from lateral line to anal fin (Lat.A.).

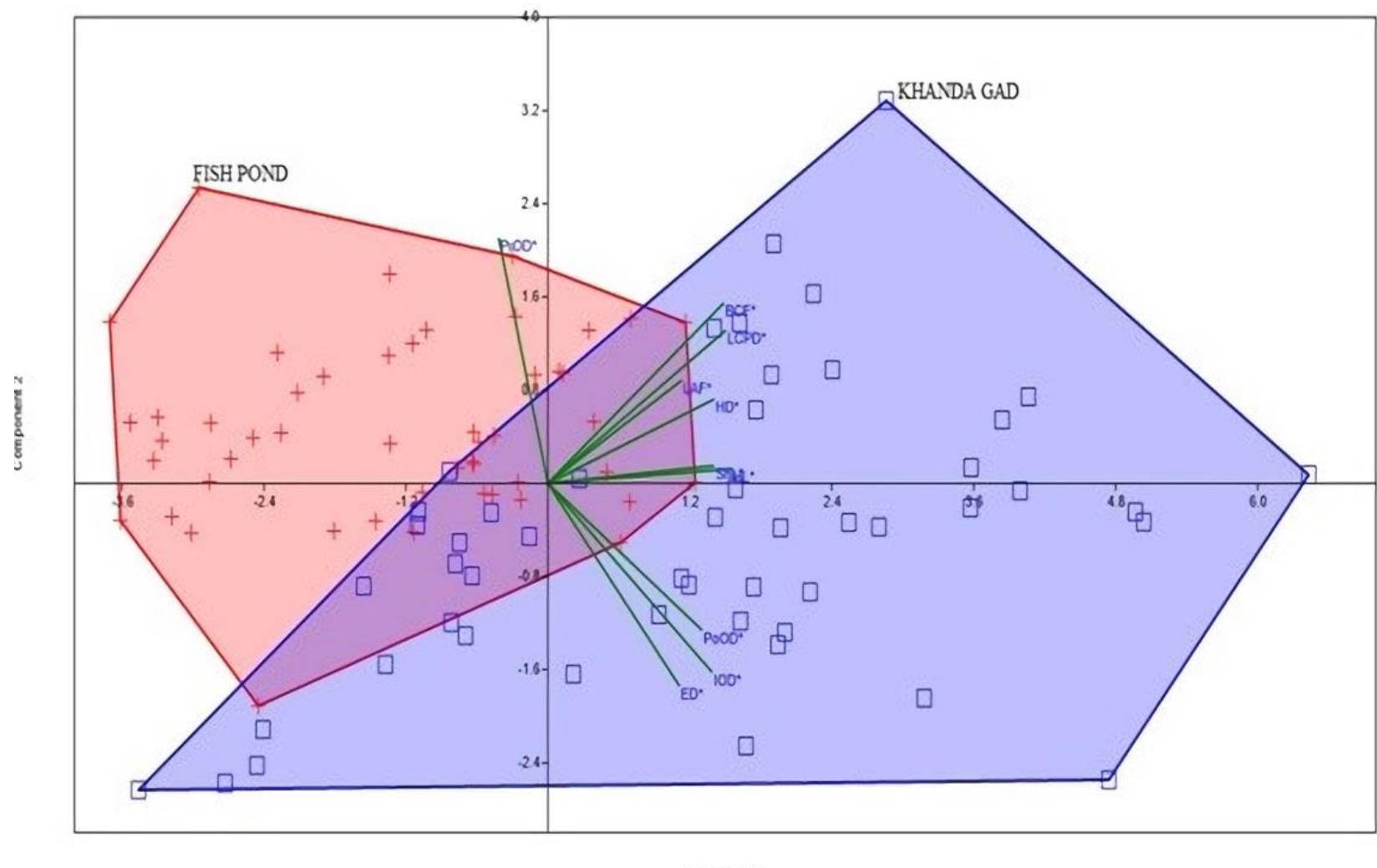

Figure 1. Principal component analysis of Barilius bendelisis based on 10 significant morphometric characters 


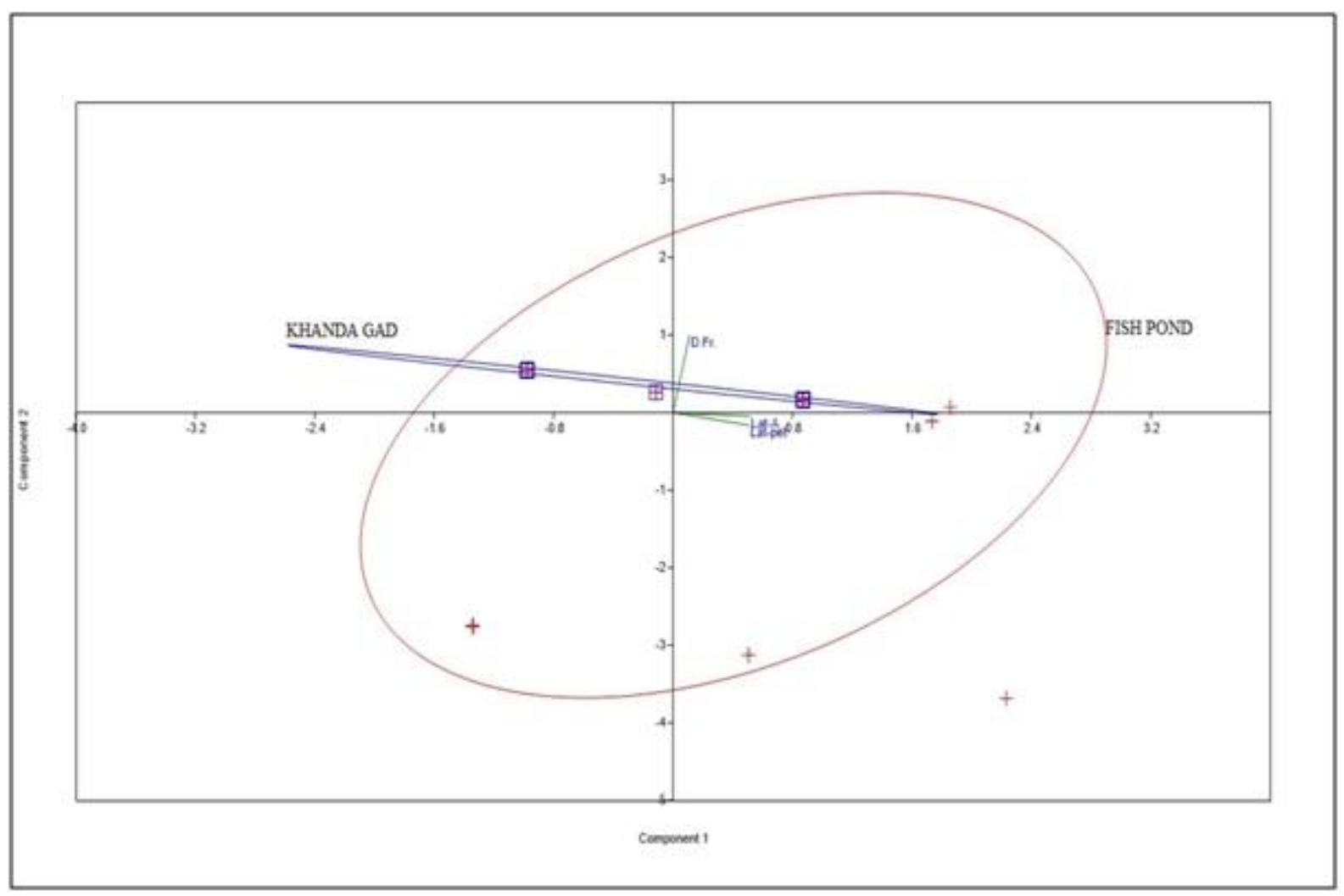

Figure 2. Principal component analysis (PCA) of Barilius bendelisis based on 3 significant meristic characters

the single function explained $100 \%$ variation at Eigen value 1.052. The Lat.Pel., Lat.A., D.Fr. Circum. are responsible for the maximum variation on this factor (Table 6). Principal component analysis (PCA) suggests the similar variables responsible for differentiating the fish population from the stream and fish pond.

Discriminant function analysis (DFA) for morphometric variables suggests that $98 \%$ of individuals were allocated into their original populations. In the cross-validation test $91 \%$ of samples were correctly classified. The percentage of the correctly classified fishes was similar in Khanda Gad and the fish pond with 98\% correct classification and $2 \%$ individuals were misclassified. So, the sensitivity and specificity of the sample classification is $98 \%$ (Table 7). Similarly, for meristic variables, DFA showed $83 \%$ of individuals were allocated into their original population, while in the cross-validation test $81 \%$ of samples were correctly classified. The correctly classified fishes in the fish pond was $90 \%$ with $10 \%$ of misclassified individuals, and for Khanda Gad $76 \%$ of the samples were correctly classified and $24 \%$ of individuals were misclassified (Table 7). The results from PCA and DFA suggests that head and fins dimensions, were the important characters in differentiating the two stocks from both wild and farmed individuals. Morphometric observations of fishes from two different sites showed that in comparison to the fishes of stream, cultured fish had slightly larger head depth, longer fins and wider abdomen. As in cultured condition, due to the decline in swimming performance and less chances of predation, the streamlining of fish body and head size reduces along with rise in depth of head and trunk [19, 20]. Furthermore, [21] observed the farmed fishes with wide abdomen and long head in comparison to wild stock, attributing these changes to the rearing condition, stock density, food availability, exposure of stress, fish mobility, swimming performance and local ecological condition [22, 23, 24, 25].

Phenotypic variations are not always suggestive of genetic segregation between populations, but might be affected by environmental conditions $[26,27]$. The shape of the cultured fish, after released in wild habitat attains the wild like body shape after a considerable period of about half a year [24]. Therefore, the morphometric variations observed in this study between wild and cultured fishes could be partially explained by habitat and 
Table 6. Pooled within-groups correlations between discriminating variables and standardized canonical discriminant functions (Variables ordered by absolute size of correlation within function)

\begin{tabular}{ccccc}
\hline \multirow{2}{*}{$\begin{array}{c}\text { Morphometric } \\
\text { Characters }\end{array}$} & Function & Morphometric & Function \\
\cline { 2 - 2 } & DF1 (100\%) & Characters & DF1 (100\%) \\
\hline ED & 0.487 & CL & 0.054 \\
PrOD & -0.420 & PPD & -0.049 \\
PoOD & 0.340 & IND & -0.048 \\
IOD & 0.321 & PoDL & -0.047 \\
SnL & 0.264 & WPF & 0.046 \\
LCPD & 0.256 & PrDL & -0.003 \\
HL & 0.256 & Eigen value & 2.594 \\
HD & 0.249 & Meristic Characters & \\
BCF & 0.220 & Lat.Pel. & -0.483 \\
LAF & 0.207 & Lat.A. & -0.456 \\
WDF & 0.151 & D.Fr. & 0.345 \\
WAF & 0.151 & Circum. & 0.313 \\
WPecF & 0.148 & Lat.D. & -0.162 \\
HCPD & 0.131 & A.Fr. & 0.157 \\
LPF & 0.129 & Pre.As. & -0.154 \\
LDF & 0.126 & Ltr.trs. & 0.124 \\
LPecF & 0.102 & Pr.Ds. & 0.091 \\
BD & 0.061 & Ltr.Ln. & -0.085 \\
& & Eigen value & 1.052 \\
\hline
\end{tabular}

Eye diameter (ED), Pre-orbital distance (PrOD), Post-orbital distance (PoOD), Inter orbital distance (IOD), Snout length (SnL), Least height of caudal peduncle (LCPD), Head Length (HL), Head depth (HD), Base of Caudal fin (BCF), Length of anal fin (LAF), Width of dorsal fin (WDF), Width of anal fin (WAF), Width of pectoral fin (Wpec.F), Highest height of caudal peduncle (HCPD), Length of pelvic fin (LPF), Length of dorsal fin (LDF), Length of pectoral fin (Lpec.F), Body Depth (BD), Caudal Length (CL), Pre-pelvic distance (PPD), Inter nostril distance (IND), Post-dorsal distance (PoDL), Width of pelvic fin (WPF), Pre-dorsal distance (PrDL), Scales from lateral line to pelvic fin (Lat.Pel.), Scales from lateral line to anal fin (Lat.A.), Dorsal fin ray (D.Fr.), Circumpenduncular scales (Circum.), Scales from lateral line to dorsal fin (Lat.D.), Anal fin ray (A.Fr.), Pre-Anal scales (Pre.As.), Lateral transverse scales (Ltr.trs.), Pre-dorsal scales (Pr.Ds.), Lateral line scales count (Ltr.Ln.).

to predators which influences the changes in the shape of the body [28].

dietary shifts, swimming adaptation and exposure to predators which influences the changes in the shape of the body [28].

\section{Cluster Analysis}

Significant morphometric characters of fish population from stream and fish pond were analyzed. Majorly two clades cluster were formed which significantly differentiate the two samples of fish population (Figure 3).

\section{Conclusion}

The scatter plot of PCA for morphometric cha- racters showed variation in stream population from the fish pond population by the characters of BCF, LCPD, ED, PrOD, PoOD and IOD; and the scatter plot of PCA for meristic character showed that D.Fr., Lat.Pel. and Lat.A. distinguish the two different fish population. Similarly, in DFA, single discriminant function explains $100 \%$ of variation in morpho-meristic characters of wild and cultured stock of $B$. bendelisis (Ham.). The cluster analysis for both the samples from stream and fish pond showed the significant difference among these two populations. Thus, it can be concluded that the fish samples of $B$. bendelisis (Ham.) from 
Table 7. Counts and percentage of specimens classified in each group and after cross validation of morphometric and meristic measurements for B. bendelisis (Ham.) from Khanda Gad and Fish Pond

\begin{tabular}{|c|c|c|c|c|c|}
\hline \multicolumn{6}{|l|}{$\begin{array}{l}\text { Morphometric } \\
\text { measurements }\end{array}$} \\
\hline \multirow{2}{*}{ Classification } & & \multirow{2}{*}{ Site } & \multicolumn{2}{|c|}{ Predicted Group Membership } & \multirow{2}{*}{ Total } \\
\hline & & & Khanda Gad & Fish Pond & \\
\hline \multirow[t]{4}{*}{ Original } & Count & Fish Pond & 1 & 49 & 50 \\
\hline & & Khanda Gad & 49 & 1 & 50 \\
\hline & $\%$ & Fish Pond & 2 & 98 & 100 \\
\hline & & Khanda Gad & 98 & 2 & 100 \\
\hline \multirow[t]{4}{*}{ Cross-validated $^{\mathrm{b}}$} & Count & Fish Pond & 5 & 45 & 50 \\
\hline & & Khanda Gad & 46 & 4 & 50 \\
\hline & $\%$ & Fish Pond & 10 & 90 & 100 \\
\hline & & Khanda Gad & 92 & 8 & 100 \\
\hline \multicolumn{6}{|c|}{ Meristic measurements } \\
\hline \multirow[t]{4}{*}{ Original } & Count & Fish Pond & 5 & 45 & 50 \\
\hline & & Khanda Gad & 38 & 12 & 50 \\
\hline & $\%$ & Fish Pond & 10 & 90 & 100 \\
\hline & & Khanda Gad & 76 & 24 & 100 \\
\hline \multirow[t]{4}{*}{ Cross-validated ${ }^{\mathrm{b}}$} & Count & Fish Pond & 7 & 43 & 50 \\
\hline & & Khanda Gad & 38 & 12 & 50 \\
\hline & $\%$ & Fish Pond & 14 & 86 & 100 \\
\hline & & Khanda Gad & 76 & 24 & 100 \\
\hline
\end{tabular}

b. Cross validation is done only for those cases in the analysis. In cross validation, each case is classified by the functions derived from all cases other than that case.

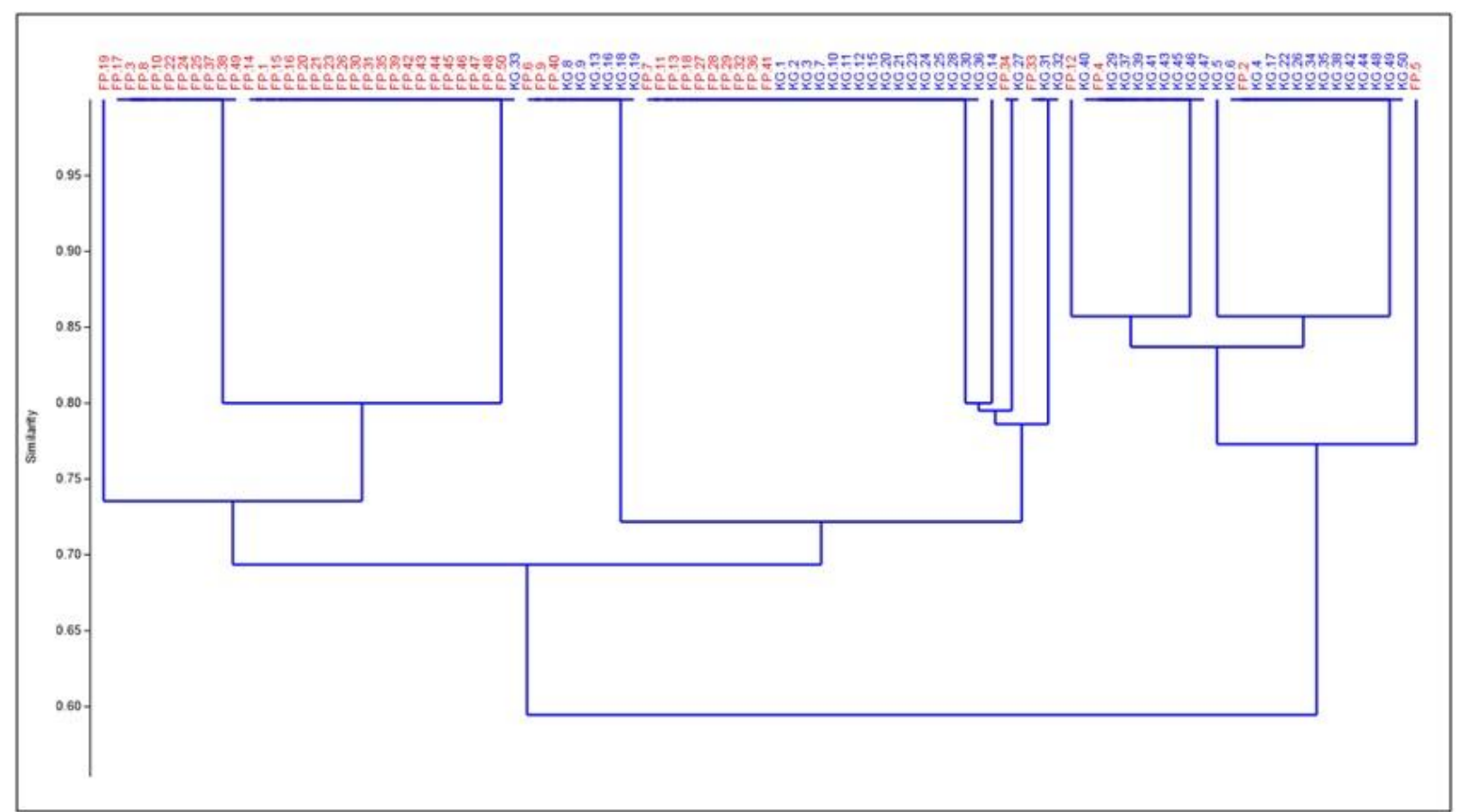

Figure 3. Cluster analysis of B. bendelisis from Khanda Gad and Fish Pond based on 10 significant morphometric characters. (KG: Khanda Gad; FP: Fish Pond) 
the wild and cultured habitat differ significantly. These morphometric variations could be attributed majorly to the rearing condition in the pond, fish mobility and swimming performance of the fish.

\section{Acknowledgement}

The authors are grateful to the Head, Department of Zoology and Biotechnology, Hemvati Nandan Bahuguna Garhwal University, Uttarakhand (India) for providing essential conveniences for the present study.

\section{References}

1. Kumar S, Singh D (2018) Intraspecific morphometric variability in the populations of Barilius bendelisis (Hamilton) from the Alaknanda basin of Central Himalaya. Journal of Applied and Natural Science 10 (4): 1199-1203. doi: 10.31018/jans.v10i4.1920.

2. Mir FA, Mir JI, Chandra S (2013) Phenotypic variation in the Snowtrout Schizothorax richardsonii (Gray, 1832) (Actinopterygii: Cypriniformes: Cyprinidae) from the Indian Himalayas. Contributions to Zoology 82 (3): 115122. doi: $10.1163 / 18759866-08203001$

3. Iqbal Mir J, Saxena N, Singh Patiyal R, Kumari Sahoo P (2015) Phenotypic differentiation of Barilius bendelisis (Cypriniformes: Cyprinidae) in four rivers from Central Indian Himalaya. Revista de Biología Tropical 63 (1): 165-173.

4. Murta AG (2000) Morphological variation of horse mackerel (Trachurus trachurus) in the Iberian and North African Atlantic: implications for stock identification. ICES Journal of Marine Science 57 (4): 1240 1248. doi: 10.1006/jmsc.2000.0810.

5. Pinheiro A, Teixeira CM, Rego AL et al. (2005) Genetic and morphological variation of Solea lascaris (Risso, 1810) along the Portuguese coast. Fisheries Research 73 (1-2): 67-78. doi: 10.1016/j.fishres.2005.01.004.

6. Buj I, Podnar M, Mrakovčić M et al. (2008) Morphological and genetic diversity of Sabanejewia balcanica in Croatia. Folia Zoologica 57 (1-2): 100-10.

7. Torres R, Gonzalez P, Pena S (2010) Anatomical, histological and ultraestructural description of the gills and liver of the Tilapia (Oreochromis niloticus). International Journal of Morphology 28 (3): 703-712. doi: 10.4067/S0717-95022010000300008.

8. Einum S, Fleming IA (2001) Implications of stocking: ecological interactions between wild and released salmonids. Nordic Journal of Freshwater Research 75: 56-70.

9. Scheiner SM (1993) Genetics and evolution of phenotypic plasticity. Annual review of ecology and systematics 24 (1): 35-68.
10. Talwar PK, Jhingran AG (1991) Inland fishes of India and adjacent countries. Oxford-IBH Publishing Co. Pvt. Ltd., New Delhi.

11. Rajbanshi KG, Csavas I (1982) Bhutan Aquaculture Development in Bhutan - a report prepared for the Establishment of Fish Seed Production Centre Project. FAO FI:DP/BHU80/007, Field Doc.

12. Oo W (2002) Inland fisheries of the Union of Myanmar. In: Petr T, Swar DB, Swar SB, eds. Cold Water Fisheries in the Trans-Himalayan Countries. Food and Agriculture Organization, 431.

13. Badola SP (2009) Ichthyology of the Central Himalaya. India: Transmedia Publication House, Srinagar (Uttarakhand).

14. Sah S, Barat A, Pande V et al. (2011) Population structure of Indian Hill Trout (Barilius bendelisis) inferred from variation in Mitochondrial DNA sequences. Advances in Biological Research 5 (2): 93-98.

15. Jayaram KC (2002) Fundamentals of fish taxonomy. Narendra Publishing House, Delhi.

16. Elliott NG, Haskard K, Koslow JA (1995) Morphometric analysis of orange roughy (Hoplostethus atlanticus) off the continental slope of southern Australia. Journal of Fish Biology 46 (2): 202-220. doi: 10.1111/j.10958649.1995.tb05962.x.

17. Johal MS, Kaur A (2005) Morphometry and Barilius bendelisis (Ham., 1822) from hillstreams of Himachal Pradesh, India. In Proceedings of the national seminar on New trends in fishery development in India. Punjab University, Chandigarh. 23-28.

18. Johal MS, Tandon KK, Sandhu GS (1994) Morphometry of Tor putitora (Mahseer) in lacustrine waters Gobind Sagar reservoir. In: Nautiyal P, eds. Mahseer the game fish. Jagdamba Prakashan Publishers, Dehradun, Rachna, Srinagar, Garhwal, B. 67-85.

19. Hard JJ, Berejikian BA, Tezak EP et al. (2000) Evidence for morphometric differentiation of wild and captively reared adult Coho salmon: a geometric analysis. Environmental Biology of Fishes 58 (1): 61-73. doi: 10.1023/A:1007646332666.

20. Kim SK, Yoon SC, Youn SH et al. (2013) Morphometric changes in the cultured starry flounder, Platichthys stellatus, in open marine ranching areas. Journal of Environmental Biology 34: 197-204.

21. Patiyal RS, Mir JI, Sharma RC et al. (2014) Pattern of meristic and morphometric variations between wild and captive stocks of endangered Tor putitora (Hamilton, 1822) using multivariate statistical analysis methods. Proceedings of the National Academy of Sciences, India Section B: Biological Sciences 84 (1): 123-129. doi: 10.1007/s40011-013-0206-6. 
22. Hanson KC, Hasler CT, Suski, CD, Cooke SJ (2007) Morphological correlates of swimming activity in wild largemouth bass (Micropterus salmoides) in their natural environment. Comparative Biochemistry and Physiology Part A: Molecular and Integrative Physiology 148 (4): 913-920. doi: 10.1016/j.cbpa.2007.09.013.

23. Basaran F, Ozbilgin H, Ozbilgin YD (2007) Compari son of the swimming performance of farmed and wild gilthead sea bream, Sparus aurata. Aquaculture Research 38 (5): 452-456. doi: 10.1111/j.13652109.2007.01670.x.

24. Rogdakis YG, Koukou KK, Ramfos A et al. (2011) Comparative morphology of wild, farmed and hatcheryreleased gilthead sea bream (Sparus aurata) in western Greece. International Journal of Fisheries and Aquaculture 3 (1): 1-9.
25. Ahmad MF, Iqbal MJ, Chandra S (2014) Detection of morphometric differentiation in Sattar snowtrout, Schizothorax curvifrons (Cypriniformes: Cyprinidae) from Kashmir Himalaya using a truss network system. Revista de Biologia Tropical 62 (1): 132-141.

26. Turan C (1999) A note on the examination of morphometric differentiation among fish populations: the truss system. Turkish Journal of Zoology 23 (3): 259-264.

27. Swain DP, Foote CJ (1999) Stocks and chameleons: the use of phenotypic variation in stock identification. Fisheries Research 43 (1-3): 113-128. doi: 10.1016/S01657836(99)00069-7.

28. Keast A (1978) Trophic and spatial interrelationships in the fish species of an Ontario temperate lake. Environmental Biology of Fishes 3 (1): 7-31. doi: 10.1007/BF00006306. 